\title{
Analisis Ward and Peppard Model Pada Strategi Bisnis dan Perencanaan Strategis Sistem Informasi
}

\author{
Daim Azhari Parinduri ${ }^{1, *}$, Roslina $^{2}$, Zakarias Situmorang ${ }^{3}$ \\ ${ }^{1}$ Fakultas Teknik dan Ilmu Komputer, Prodi Magister Ilmu Komputer, Universitas Potensi Utama, Medan, Indonesia \\ ${ }^{2}$ Politeknik Negeri Medan, Medan, Indonesia \\ ${ }^{3}$ Universitas Katolik Santo Thomas Medan, Medan, Indonesia \\ e-mail: 1,*daimazhari@gmail.com, ${ }^{2}$ roslinanich@gmail.com, ${ }^{3}$ zakarias65@yahoo.com \\ Email Penulis Korespondensi: daimazhari@gmail.com
}

\begin{abstract}
Abstrak-Universitas Muslim Nusantara Al-Washliyah merupakan perguruan tinggi swasta yang sudah memiliki teknologi sistem informasi dan teknologi informasi sebagai upaya untuk meningkatkan daya saing perguruan tinggi. Namun keberadaan sistem informasi yang ada masih belum dikatakan sempurna sehingga pekerjaan menjadi tidak efisien. Maka dari itu, penelitian ini dilakukan untuk membuat perencanaan strategis sistem informasi sehingga dapat meningkatkan daya saing perguruan tinggi. Model yang digunakan dalam perencanaan strategis pada penelitian ini adalah Model Ward dan Peppard. Rencana strategis disusun untuk kerangka waktu selama 2 tahap. Prosesnya diawali dengan Analisis Bisnis Internal dan Eksternal melalui Analisis SWOT, Analisis Value Chain, Analisis PEST serta pengujian hasil strategi menggunakan metode Profile Matching yang menjadi pilihan guna memberikan penilaian terhadap aplikasi sistem informasi yang direkomendasikan. Ada tiga aspek dalam melakukan penilaian dan evaluasi tersebut, yaitu aspek baru, kembangkan dan lanjutkan.
\end{abstract}

Kata Kunci: Perencanaan Strategis; Ward and Peppard; Profile Matching

Abstract-Muslim Nusantara Al-Washliyah University is a private university that already has information system technology and information technology as an effort to improve the competitiveness of higher education. However, the existence of the existing information system is still not perfect so that work becomes inefficient. Therefore, this research was conducted to make strategic planning of information systems so as to increase the competitiveness of higher education institutions. The model used in strategic planning in this study is the Ward and Peppard model. The strategic plan is drawn up for a timeframe of 2 phases. The process begins with Internal and External Business Analysis through SWOT Analysis, Value Chain Analysis, PEST Analysis and testing of strategy results using the Profile Matching method which is the choice to provide an assessment of recommended information system applications. There are three aspects in conducting the assessment and evaluation, namely new aspects, develop and continue.

Keywords: Strategic Planning; Ward and Peppard; Profile Matching

\section{PENDAHULUAN}

Pada mulanya metode perencanaan SI/TI yang dikembangkan oleh Ward and Peppard diterapkan pada suatu perusahaan yang tujuan utamanya mencari keuntungan dari proses bisnisnya, namun seiring berjalan nya waktu metode Ward and Peppard dapat diterapkan pada organisasi pemerintah atau swasta yang orientasi proses bisnisnya pada pelayanan publik[1]. Metode Ward dan peppard mempunyai kelebihan dan kekurangannya di mana kelebihan metode ini dapat menghasilkan usulan - usulan strategis yang mendukung perusahaan dan memiliki kerangka kerja yang jelas dan lebih cocok digunakan pada kondisi perusahaan saat ini Tools yang digunakan untuk mendukung metode ini adalah analisis SWOT untuk menghasilkan strategis usulan mengenai bisnis internal dan eksternal, Value chain untuk mengetahui kontribusi SI/TI pada fungsi bisnis perusahaan, strategis SI bisnis, McFarlan strategic grid untuk menentukan portofolio aplikasi sehingga perusahaan dapat meningkatkan kinerja[2].

Salah satu jenis kegiatan bisnis adalah lembaga perguruan tinggi dimana perguruan tinggi termasuk jenis bisnis dengan produk jasa. Setiap lembaga perguruan tinggi tentunya memiliki prioritas utama berupa pelayanan pendidikan berdasarkan visi dan misi perguran tinggi tersebut. Berbagai strategi bisnis pada lembaga perguruan tinggi swasta perlu dirancang agar ke depan Perguruan tingi tersebut memiliki daya tahan terhadap pesaingnya yang bergerak di bidang yang sama serta memiliki pandangan bersikap.Kemampuan masyarakat menilai kualitas dalam pemilihan perguruan tinggi swasta untuk memperoleh pendidikan di jenjang yang lebih tinggi juga menjadi pertimbangan perlunya perancangan strategi bisnis ini [3].

Beberapa penelitian terdahulu yang sudah dilakukan menggunakan metode Ward and Peppard dan metode Profile Matching antara lain:

1. Penelitian yang berjudul Perencanaan Strategis Sistem Informasi Perusahaan Dengan Pendekatan Model Ward And Peppard (Studi Kasus Pg.Fanada Super Plered Purwakarta) [4]. Hasil dari penelitian ini akan digambarkan dalam bentuk tabel portofolio aplikasi yang dibagi menjadi 4 kuadran yaitu Strategy, Key Operasional, High Potensial dan Support.dan di harapkan mampu meningkatkan kompetensi perusahaan dan kompetensi pegawai sehingga strategis perusahaan akan tercapai sesuai visi, misi dan tujuan perusahaan.

2. Penelitian yang berjudul Perencanaan Strategis Sistem Informasi Dengan Pendekatan Ward And Peppard Model (Studi Kasus: Klinik Inti Garut)[5]. penelitian ini menghasilkan sebuah rekomendasi untuk organisasi 
berupa prioritas pembangunan yang terbagi menjadi dua halhal terkait, pembentukan unit SI/TI dan pengembangan portofolio aplikasi yang akan mendukung keberlangsungan proses bisnis Klinik INTI Garut.[6](Adriyendi, 2015)(Adriyendi, 2015)(Adriyendi, 2015)(Adriyendi, 2015)(Adriyendi, 2015)(Adriyendi, 2015)(Adriyendi, 2015)(Adriyendi, 2015)(Adriyendi, 2015)(Adriyendi, 2015)(Adriyendi, 2015)(Adriyendi, 2015)(Adriyendi, 2015)(Adriyendi, 2015)(Adriyendi, 2015)(Adriyendi, 2015)(Adriyendi, 2015)

3. Penelitian yang berjudul Sistem Pendukung Keputusan Pemilihan Kategori Promosi Produk Menggunakan Metode Profile Matching (Studi Kasus : Minimarket) [7]. Penelitian ini bertujuan memberikan solusi kepada perusahaan dalam mengambil keputusan pemilihan kategori promosi produk dengan menggunakan metode profile matching karena metode ini telah banyak digunakan dalam berbagai bidang untuk sistem pendukung keputusan. Pengambilan keputusan kategori promosi produk dilakukan dengan melihat tiga aspek yaitu budget, penjualan dan waktu promosi dengan pemberian bobot terhadap aspek yang telah ditentukan, perhitungan nilai core factor (NCF) dan nilai secondary factor (NSF), perhitungan nilai total akan menghasilkan rekomendasi kategori promosi produk. Ada empat kategori yang akan menjadi hasil rekomendasi untuk setiap promosi produk yaitu Rafaksi, Mailer, Discount dan Listing. Dengan dilakukannya penelitian ini akan membantu perusahaan distributor dalam menentukan promo untuk setiap produk yang dimiliki.

Dari 2 judul penelitian yang berjudul Penelitian yang berjudul Perencanaan Strategis Sistem Informasi Perusahaan Dengan Pendekatan Model Ward And Peppard (Studi Kasus Pg.Fanada Super Plered Purwakarta) dan penelitian yang berjudul Perencanaan Strategis Sistem Informasi Dengan Pendekatan Ward And Peppard Model (Studi Kasus: Klinik Inti Garut), di sini dapat di buktikan bahwa setiap strategi yang sudah di tetapkan oleh penulis belum di uji tingkat akurasi nya sehingga belum terjamin strategi yang sudah di tetapkan nya berjalan sesuai yang di harapkan.maka dari pada itu penelitian ini di kembangkan kembali dengan proses nya menggunakan metode ward and peppard akan tetapi di kembangkan dengan menambahkan alat uji metode tersebut dengan menggunakan metode Metode Profile Matching seperti penelitian yang berjudul Sistem Pendukung Keputusan Pemilihan Kategori Promosi Produk Menggunakan Metode Profile Matching (Studi Kasus : Minimarket).

Hal inilah yang menjadi dasar pemikiran bahwa perusahaan membutuhkan sebuah metode Profile Matching berupa sistem pendukung keputusan agar pemilihan kategori promosi produk tepat sasaran sehingga tujuan utama pengadaaan strategi tersebut dapat tercapai. Secara garis besar penelitian ini merupakan upaya untuk membangun suatu perencanaan strategis sistem informasi berupa aplikasi di UMN Al-Washliyah yang bisa memberikan kontribusi yang optimal, handal, terintegrasi dengan baik dan bisa menyatukan keseluruhan aspek pendukung dalam pencapaian strategi bisnis Perguruan untuk meningkatkan nilai kualitas nya dalam jasa pelayanan pendidikan dan dapat di uji tingkat keakuratannya.

\section{METODOLOGI PENELITIAN}

Metode Perencanaan Strategi SI/TI versi Ward dan Peppard merupakan metode yang komprehensif, dimana metode ini terlebih dahulu dimulai dari kegiatan assesment dan pemahaman terhadap situasi saat ini baik terhadap lingkungan bisnis maupun lingkungan SI/TI. Lingkungan bisnis meliputi lingkungan bisnis internal dan lingkungan bisnis eksternal. Demikian juga dengan lingkungan SI/TI yang meliputi lingkungan SI/TI internal dan eksternal. Dengan pemahaman yang mendalam terhadap kondisi saat ini, maka dapat ditentukan strategi sistem informasi (SI), strategi teknologi informasi (TI) dan strategi SI/TI masa mendatang (future) secara tepat [8]

Profile matching adalah sebuah mekanisme pengambilan keputusan dengan mengasumsikan bahwa terdapat tingkat variabel prediktor yang ideal yang harus dipenuhi oleh subyek yang diteliti, bukannya tingkat minimal yang harus dipenuhi atau dilewati [9]. Dalam proses profile matching secara garis besar merupakan proses membandingkan antara setiap kriteria setiap penilaian dalam sebuah proposal usulan penelitian yang diajukan sehingga diketahuiperbedaan skornya (disebut juga GAP (Gains Across Product)), semakin kecil GAP yang dihasilkan maka bobot nilainya semakin besar yang berarti memiliki peluang lebihbesar untuk prioritas kelayakan/kelulusan[10]. Nilai GAP adalah nilai selisih value masing masing atribut dengan value target, dapat dihitung menggunakan persamaan yaitu[11]:

$$
\text { GAP = Value Atribut }- \text { Value Target }
$$

Setelah menentukan bobot nilai gap untuk semua aspek dengan cara yang sama, setiap aspek dibagi lagi menjadi dua kelompok yaitu kelompok Core Factor dan Secondary Factor. Perhitungan Core Factor dapat ditunjukkan pada persamaan dibawah ini:

$$
N C F=\frac{\Sigma N C(a, n)}{\Sigma I C}
$$

Dimana: 
ISSN 2614-5278 (media cetak), ISSN 2548-8368 (media online)

Available Online at https://ejurnal.stmik-budidarma.ac.id/index.php/mib DOI 10.30865/mib.v5i2.2977

NCF = Nilai rata-rata core factor

$\mathrm{NC}(\mathrm{a}, \mathrm{n})=$ Jumlah total nilai core factor $($ aspek)

IC = Jumlah item core factor

Perhitungan Secondary Factor dapat ditunjukkan pada persamaan dibawah ini:

$$
N S F=\frac{\Sigma N S(a, n)}{\Sigma I C}
$$

Setelah mendapatkan nilai NCF dan NSF maka akan dilakukan perhitungan nilai total dengan rumus $70 \%$ NCF ditambah $30 \%$ NSF menggunakan rumus sebagai berikut:

$$
N(a, n)=(x) \% N C F(a, n)+(x) \% N S F(a, n)
$$

Dimana:

$\mathrm{N}(\mathrm{a}, \mathrm{n})=$ Total nilai aspek kategori strategi

SI $(\mathrm{x}) \%=$ Nilai persen yang diinput

$\operatorname{NCF}(a, n)=$ Nilai rata-rata core factor

$\mathrm{NSF}(\mathrm{a}, \mathrm{n})=$ Nilai rata-rata secondary factor

\subsection{Perencanaan Strategis SI/TI dengan Pendekatan Ward and Peppard Model}

Metodologi perencanaan strategis SI/TI yang akan digunakan adalah metode perencanaan strategis berdasarkan Ward and Peppard Model. Ward dan Peppard menyajikan suatu model analisa tentang hal ini yang diwujudkan dalam bangun kotak kotak yang menggambarkan bagian masukan, keluaran dan aktifitas-aktifitas pokoknya, seperti terlihat pada Gambar 1.

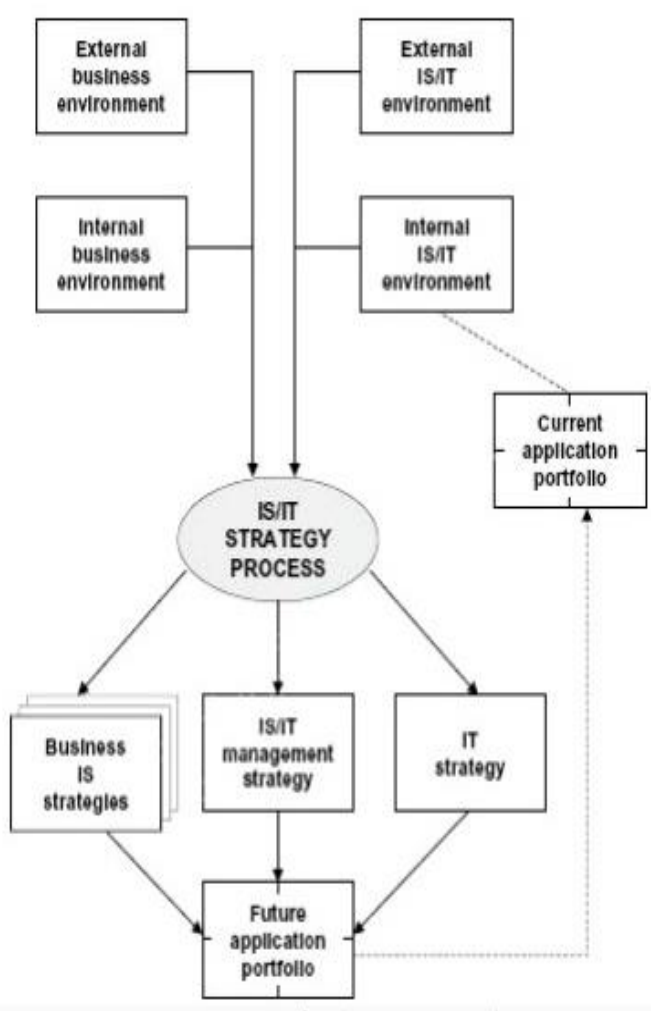

Gambar 1. Model Framework Perencanaan Strategi SI atau TI

\subsubsection{Penentuan Strategi Bisnis}

(Sumber: Ward dan Peppard, 2002)

Dalam melakukan penentuan strategi bisnis langkah pertama di lakukan teknik pengumpulan data berupa: Observasi, Wawancara, Studi Kepustakaan dan Analisis Dokumen.selanjutnya melakukan Analisis bisnis internal dan eksternal dengan menggunakan metode/teknik Value Chain Analysis, SWOT Analysis, dan PEST Analysis [12]. Kemudian melakukan analisis lingkungan SI/TI yang meliputi hardware, software dan infrastruktur SI/TI yang ada saat ini.

\subsection{Pengujian Hasil Strategi dengan Metode Profile Matching}


Pada tahap pengujian ini Penulis menggunakan metode profile matching dengan melihat aspek beberpa aplikasi SI yang sudah di tentukan [13]. Beberapa tahapan yang penulis gunakan dalam penelitian pengujian SI ini adalah:

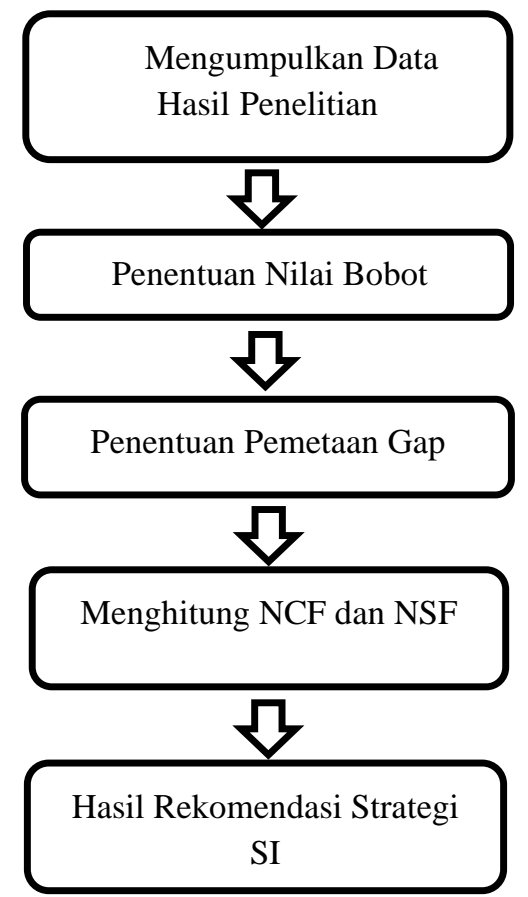

Gambar 2. Tahapan Pengujian

\section{HASIL DAN PEMBAHASAN}

Bagian ini akan menganalisis hasil masalah yang telah dijelaskan pada bab sebelumnya. Penelitian ini dilaksanakan sesuai tahapan yang telah di tentukan mulai dari Teknik Pengumpulan Data dengan rincian wawancara, observasi, analisis dokumen dan studi kepustakaan. Nanti nya setelah di susun strategi Ward and peppard baru lah akan di uji menggunakan metode profile matching.

\subsection{Metode Perencanaan Strategis Sistem Informasi Ward and Peppard}

\subsubsection{Analisis SWOT}

Hasil analisis SWOT yang sudah dilakukan oleh UMN Al-Washliyah yang tercantum dalam dokumen rencana strategi sesuai dengan 4 komponen dasar dan beberapa tambahan analisis setelah melakukan observasi, wawancara, analisis dokumen dan studi kepustakaan yaitu:

\section{A. Kekuatan (Strength)}

Kampus UMN Al-Washliyah Memiliki visi, misi dan tujuan yang jelas dengan ber cirikan kampus yang menjunjung tinggi nilai Islami dan memiliki Akreditasi Institusi B sejak tahun 2017 sampai 2022. Terdiri dari 19 Program studi dengan rincian 15 Program studi Strata 1 dan 4 program studi Strata 2 dan tahun 2020 di percaya oleh Kemendikbud menjadi salah satu Perguruan tinggi swasta di Sumatera Utara sebagai pelaksana Pendidikan Profesi Guru (PPG). UMN Al-Washliyah pernah menduduki Peringkat 182 Perguruan Tinggi di Indonesia dan mendapatkan peringkat ke 2 Perguruan Tinggi Swasta tingkat provinsi Sumatera Utara [14].

\section{B. Kelemahan (Weakness)}

Penggunaan Teknologi Informasi rendah, aktivitas belajar mengajar secara daring terkendala akibat fasilitas server kurang memadai. jumlah dosen yang menyandang status guru besar sedikit. Rekapitulasi jumlah pendaftar mahasiswa baru dalam tiga tahun terakhir (2018 -2020) mengalami penurunan.

\section{Peluang (Opportunity)}

Adanya MOU yang baik dengan beberapa Universitas, beberapa Dinas di lingkungan pemerintah maupun lembaga swasta baik dalam maupun luar negeri yang dapat memberi peluang terhadap pengembangan dan pemberdayaan kelembagaan berupa Pertukaran mahasiswa, pemberian beasiswa studi, bantuan penelitian, pelatihan pengembangan SDM.

\section{Ancaman (Threat)}


Semakin banyak perguruan tinggi swasta di Sumatera Utara yang terus tumbuh professional dengan memanfaat kan kecanggihan teknologi sehingga menjadi kompetitor bagi UMN Al-Washliyah untuk bersaing mendapatkan input yang berkualitas.

\subsubsection{Analisis Value Chain}

Hasil dari Analisis Value Chain di tinjau dari aktivitas utama dan aktivitas pendukung seperti pada gambar 3.

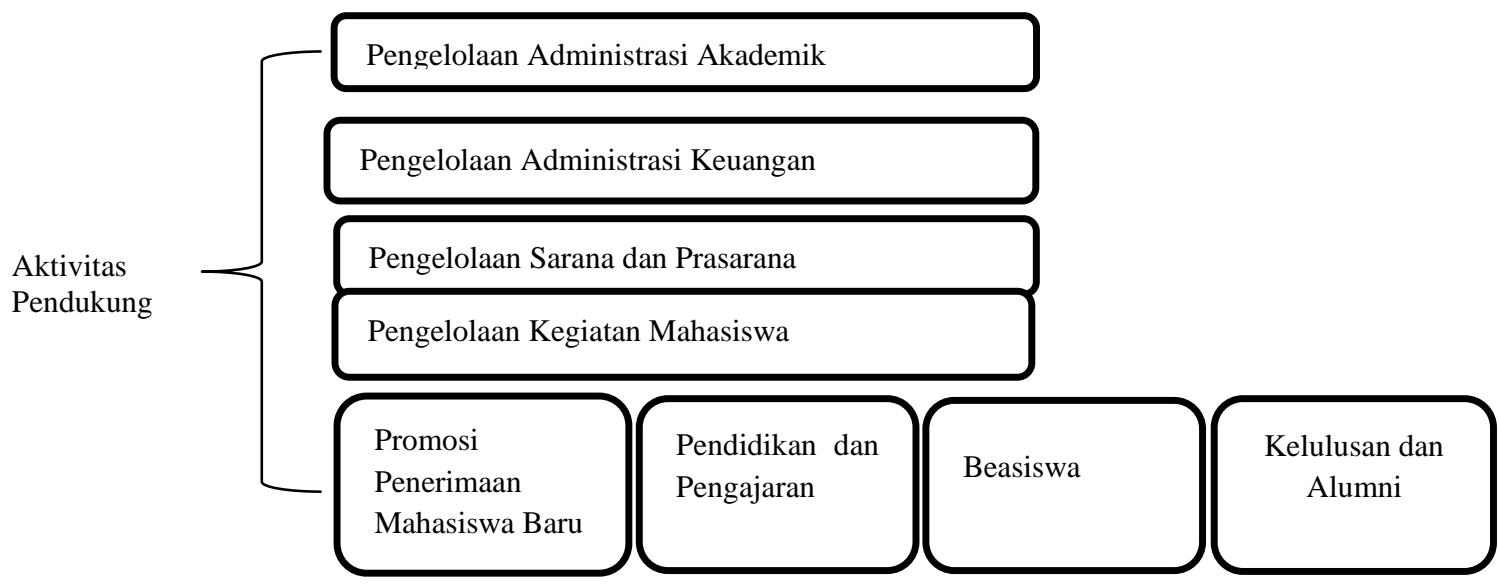

Gambar 3. Hasil Analisis Value Chan

\subsubsection{Analisis PEST}

Berikut Hasil Analisis PEST berdasarkan hasil observasi dan wawancara diantara nya:

1. Faktor Politik

a. Undang-Undang Republik Indonesia Nomor 20 Tahun 2003 Tentang Sistem Pendidikan Nasional [15]

b. Peraturan menteri Riset, Teknologi, Dan Pendidikan Tinggi republik Indonesia nomor44 Tahun 2015 tentang Standar Nasional Pendidikan Tinggi [16].

2. Faktor Ekonomi

Pandemi virus corona yang berlangsung sepanjang tahun 2020 ini tak hanya berdampak pada sektor Kesehatan dampak pandemi juga terjadi pada sektor ekonomi dunia dan banyak negara, termasuk Indonesia. Indonesia resmi mengalami resesi setelah pertumbuhan minus pada dua kuartal secara berturut-turut.

3. Faktor Sosial

Pemahaman keagamaan seseorang dapat berpengaruh terhadap sikap dan perilaku orang tersebut. Jika pemahaman keagamaannya baik, maka sikap dan perilakunya akan baik.dari hasil penjelasan tersebut dapat dikatakan bahwa UMN Al-Washliyah merupakan salah satu perguruan tinggi swasta di Sumatera Utara yang menjunjung tinggi nilai nilai keagamaan di lingkungan nya.hal ini dapat di buktikan dengan mencantum kan mata kuliah yang bersifat keagaaman di antara nya Ilmu Tauhid dan Kealwashliyahaan.hal ini ini di lakukan untuk menghindari gerakan gerakan yang bersifat Radikalisme dan terorisme.

4. Faktor Teknologi

Di Zaman Era Industri 4.0 perkembangan teknologi informasi telah menyentuh berbagai bidang kehidupan. Apabila tidak dimanfaatkan dengan maksimal, maka akan tertinggal oleh kemajuan zaman. Teknologi informasi dapat pula dimanfaatkan sebagai strategi yang sangat jitu untuk meningkatkan keunggulan dalam bersaing.

\subsubsection{Portofolio Aplikasi SI}

Dalam penyusunan portofolio sebuah aplikasi dapat dikategorikan menjadi 4 kategori yaitu sebagai Strategic, High Potential, key operational atau support.

a. Strategic Merupakan aplikasi yang bersifat sangat penting bagi institusi dan digunakan sebagai alat untuk mencapai tujuan utama agar institusi dapat bertahan atau terus berkembang di masa yang akan datang. Aplikasi tersebut adalah website, akun media sosial, SI Pendaftaran Mahasiswa Baru

b. Key Operational Merupakan aplikasi yang menunjang kelangsungan operasi institusi yang sudah ada, membantu institusi terhindar dari kerugian. Jika aplikasi tersebut mengalami gangguan maka kelangsungan bisnis akan terganggu. Aplikasi tersebut adalah SI Akademik, SI Kepegawaian, SI Perpustakaan, SI Keuangan, SI Penjaminan Mutu.

c. Support Merupakan salah satu aplikasi yang penting untuk mencapai tujuan dan strategi bisnis UMN AlWashliyah tapi tetapi tidak menunjang institusi untuk keuntungan kompetitif. Aplikasi tersebut adalah EJournal, SI Inventaris, SI Tracer Study, SI Kerjasama, SI Beasiswa dan SI Kemahasiswaan.

d. Hight Potential Merupakan aplikasi inovatif yang mungkin dapat membuat peluang bagi perusahaan untuk mendapatkan keuntungan di masa yang akan datang tetapi belum terbukti. 


\subsection{Pengujian Hasil Strategi}

\subsubsection{Penentuan Nilai Bobot}

Jenis pengujian penelitian ini adalah penelitian pengembangan yaitu pengembangan system pendukung keputusan dengan metode Profile Matching pada proses perancangan strategis SI pada UMN Al-Washliyah. Langkah awal adalah penentuan Aspek dan penentuan nilai bobot untuk tiap Aspek.

Ada 3 aspek yang tertera yang mana aspek susuai dengan rekomendasi SI yang di uraikan. untuk keterangan Aspek dan nilai bobot untuk tiap aspek nya dapat di lihat pada table 1,2 dan 3

Tabel 1. nilai tiap Aspek Baru

\begin{tabular}{clll}
\hline No & \multicolumn{1}{c}{ Nilai } & & Bobot \\
\hline 1 & $75-100$ & 4 & \\
2 & $50-74,9$ & 3 & \\
3 & $25-49,9$ & 2 & \\
4 & $0-24,9$ & 1 & \\
\hline
\end{tabular}

Tabel 2. nilai tiap Aspek lanjutkan

\begin{tabular}{llll}
\hline No & \multicolumn{1}{c}{ Nilai } & & Bobot \\
\hline 1 & $75-100$ & 4 & \\
2 & $50-74,9$ & 3 & \\
3 & $25-49,9$ & 2 & \\
4 & $0-24,9$ & 1 & \\
\hline
\end{tabular}

Tabel 3. nilai untuk tiap Aspek Kembangkan

\begin{tabular}{clll}
\hline No & \multicolumn{1}{c}{ Nilai } & & Bobot \\
\hline 1 & $80-100$ & 5 & \\
2 & $60-79,9$ & 4 & \\
3 & $40-50,9$ & 3 & \\
4 & $20-39,9$ & 2 & \\
5 & $0-19,9$ & 1 & \\
\hline
\end{tabular}

Selanjutnya untuk setiap aspek pada kategori SI akan dilakukan pemberian nilai oleh Bapak Edi Zulfikar S.Pd., M.Hum selaku Kepala Biro Administrasi Akademik untuk pengelompokan gap yaitu untuk kategori aspek baru (B), lanjutkan (P) dan kembangkan (W) seperti terlihat pada tabel 4.

Tabel 4. Aspek Penilaian Nilai GAP

\begin{tabular}{lllll}
\hline No & \multicolumn{1}{c}{ Nama Sistem Informasi } & B & P & W \\
\hline 1 & SI Pendaftaran Mahasiswa Baru & 3 & 2 & 4 \\
2 & Website & 4 & 2 & 4 \\
3 & Media Sosial & 2 & 4 & 5 \\
4 & SI Akademik & 4 & 2 & 4 \\
5 & SI Kepegawaian & 3 & 1 & 5 \\
6 & SI Perpustakaan & 3 & 3 & 5 \\
7 & SI Keuangan & 3 & 3 & 3 \\
8 & E-Journal & 2 & 3 & 5 \\
9 & SI Inventaris & 4 & 1 & 2 \\
10 & SI Tracer Study & 4 & 3 & 5 \\
11 & SI Kerjasama & 3 & 4 & 5 \\
12 & SI Penjaminan Mutu & 2 & 4 & 4 \\
13 & SI Beasiswa & 3 & 4 & 4 \\
14 & SI Kemahasiswaan & 4 & 3 & 3 \\
15 & SI Terintegrasi & 3 & 4 & 1 \\
\hline
\end{tabular}

\subsubsection{Pemetaan Nilai GAP}

Berdasarkan data aspek penilaian nilai GAP yang terdapat pada tabel 4.5 langkah selanjutnya adalah pemetaan nilai GAP, dimana nilai GAP merupakan selisih dari value atribut dan value target, sehingga diperoleh bobot 
masing-masing kriteria. Nilai GAP dapat diikhtisarkan dengan menggunakan data nilai bobot GAP. Untuk hasil pembobotan nilai gap dapat di lihat pada tabel 5.

Tabel 5. Hasil pembobotan nilai GAP

\begin{tabular}{ccccc}
\hline No & Nama Sistem Informasi & B & P & W \\
\hline 1 & SI Pendaftaran & -1 & -2 & -1 \\
& Mahasiswa Baru & & & \\
2 & Website & 0 & -2 & -1 \\
3 & Media Sosial & -2 & 0 & 0 \\
4 & SI Akademik & 0 & -2 & -1 \\
5 & SI Kepegawaian & -1 & -3 & 0 \\
6 & SI Perpustakaan & -1 & -1 & 1 \\
7 & SI Keuangan & -1 & -1 & -2 \\
8 & E-Journal & -2 & -1 & 0 \\
9 & SI Inventaris & 0 & -3 & -3 \\
10 & SI Tracer Study & 0 & -1 & 0 \\
11 & SI Kerjasama & -1 & -1 & 0 \\
12 & SI Penjaminan Mutu & -2 & 0 & -1 \\
13 & SI Beasiswa & -1 & 0 & -1 \\
14 & SI Kemahasiswaan & 0 & -1 & -2 \\
15 & SI Terintegrasi & -1 & 0 & -4 \\
\hline
\end{tabular}

\subsubsection{Menghitung Nilai NCF dan NSF}

Pada tahap ini di lakukan perhitungan dan pengelompokan core factor dan second factor dengan hasil seperti tabel 6. sebagai berikut.

Tabel 6. Perhitungan Nilai Core and Second Factory

\begin{tabular}{ccccccc}
\hline No & $\begin{array}{c}\text { Nama Sistem } \\
\text { Informasi }\end{array}$ & B & P & W & NCF & NSF \\
\hline 1 & SI Pendaftaran & -1 & -2 & -1 & 4 & 4,5 \\
& Mahasiswa Baru & & & & & \\
2 & Website & 0 & -2 & -1 & 4,25 & 4,5 \\
3 & Media Sosial & -2 & 0 & 0 & 4,25 & 5 \\
4 & SI Akademik & 0 & -2 & -1 & 4,25 & 4,5 \\
5 & SI Kepegawaian & -1 & -3 & 0 & 3,5 & 5 \\
6 & SI Perpustakaan & -1 & -1 & 1 & 4,5 & 4 \\
7 & SI Keuangan & -1 & -1 & -2 & 4,5 & 3,5 \\
8 & E-Journal & -2 & 0 & 0 & 4,25 & 5 \\
9 & SI Inventaris & 0 & -3 & -3 & 3,75 & 2,5 \\
10 & SI Tracer Study & 0 & -1 & 0 & 4,75 & 5 \\
11 & SI Kerjasama & -1 & -1 & 0 & 4,5 & 5 \\
12 & SI Penjaminan Mutu & -2 & 0 & -1 & 4,25 & 4,5 \\
13 & SI Beasiswa & -1 & 0 & -1 & 4,75 & 4,5 \\
14 & SI Kemahasiswaan & 0 & -1 & -2 & 4,75 & 3,5 \\
15 & SI Terintegrasi & -1 & 0 & -4 & 4,75 & 1,5 \\
\hline
\end{tabular}

Langkah selanjutnya adalah menghitung nilai total yang merupakan presentase dari nilai core factor dan secondary factor. Seperti pada tabel 7.

Tabel 7. Perhitungan nilai akhir

\begin{tabular}{cccccccc}
\hline No & $\begin{array}{c}\text { Nama Sistem } \\
\text { Informasi }\end{array}$ & B & P & W & NCF & NSF & NA \\
\hline 1 & SI Pendaftaran & -1 & -2 & -1 & 4 & 4,5 & 4.15 \\
& $\begin{array}{c}\text { Mahasiswa Baru } \\
\text { Website }\end{array}$ & 0 & -2 & -1 & 4,25 & 4,5 & 4,32 \\
2 & Media Sosial & -2 & 0 & 0 & 4,25 & 5 & 4,47 \\
3 & SI Akademik & 0 & -2 & -1 & 4,25 & 4,5 & 4,32 \\
4 & SI Kepegawaian & -1 & -3 & 0 & 3,5 & 5 & 3,95 \\
5 & & & & & &
\end{tabular}


JURNAL MEDIA INFORMATIKA BUDIDARMA

Volume 5, Nomor 2, April 2021, Page 717-725

ISSN 2614-5278 (media cetak), ISSN 2548-8368 (media online)

Available Online at https://ejurnal.stmik-budidarma.ac.id/index.php/mib

DOI 10.30865/mib.v5i2.2977

\begin{tabular}{cccccccc}
\hline No & $\begin{array}{c}\text { Nama Sistem } \\
\text { Informasi }\end{array}$ & B & P & W & NCF & NSF & NA \\
\hline 6 & SI Perpustakaan & -1 & -1 & 1 & 4,5 & 4 & 4,35 \\
7 & SI Keuangan & -1 & -1 & -2 & 4,5 & 3,5 & 4,2 \\
8 & E-Journal & -2 & 0 & 0 & 4,25 & 5 & 4,47 \\
9 & SI Inventaris & 0 & -3 & -3 & 3,75 & 2,5 & 3,37 \\
10 & SI Tracer Study & 0 & -1 & 0 & 4,75 & 5 & 4,82 \\
11 & SI Kerjasama & -1 & -1 & 0 & 4,5 & 5 & 4,65 \\
12 & SI Penjaminan Mutu & -2 & 0 & -1 & 4,25 & 4,5 & 4,32 \\
13 & SI Beasiswa & -1 & 0 & -2 & 4,75 & 4,5 & 4,67 \\
14 & SI Kemahasiswaan & 0 & -1 & -2 & 4,75 & 3,5 & 4,37 \\
15 & SI Terintegrasi & -1 & 0 & -4 & 4,75 & 1,5 & 3,77 \\
\hline
\end{tabular}

\subsubsection{Hasil Rekomendasi SI}

Pada tahap ini,akan dilakukan penentuan hasil rekomendasi SI berdasarkan ranking yang merupakan tahap akhir dari metode profile matching, rangking ditentukan berdasarkan perhitungan nilai total seperti terlihat pada tabel 8 selanjutnya nilai tersebut dihitung, yang kemudian diurutkan dari yang terbesar hingga yang terkecil.(Apriana,2019)

Tabel 8. Data Hasil Ranking

\begin{tabular}{cccc}
\hline No & Nama Sistem Informasi & $\begin{array}{c}\text { Nilai } \\
\text { Akhir }\end{array}$ & Ranking \\
\hline 1 & SI Pendaftaran Mahasiswa Baru & 4.15 & 12 \\
2 & Website & 4,32 & 10 \\
3 & Media Sosial & 4,47 & 4 \\
4 & SI Akademik & 4,32 & 8 \\
5 & SI Kepegawaian & 3,95 & 13 \\
6 & SI Perpustakaan & 4,35 & 7 \\
7 & SI Keuangan & 4,2 & 11 \\
8 & E-Journal & 4,47 & 5 \\
9 & SI Inventaris & 3,37 & 15 \\
10 & SI Tracer Study & 4,82 & 1 \\
11 & SI Kerjasama & 4,65 & 3 \\
12 & SI Penjaminan Mutu & 4,32 & 9 \\
13 & SI Beasiswa & 4,67 & 2 \\
14 & SI Kemahasiswaan & 4,37 & 6 \\
15 & SI Terintegrasi & 3,77 & 14 \\
\hline
\end{tabular}

Pada penetapan perangkingan aplikasi Tracer Study menduduki peringkat 1 dengan nilai akhir 4,82 hal ini merupakan tugas utama bagi pimpinan untuk lebih mengembangkan aplikasi tracer study dengan mengupdate data alumni secara keseluruhan serta mengupdate terus informasi seputar lowongan pekerjaan serta memberikan pelatihan kepada alumni.

\section{KESIMPULAN}

Dari hasil penelitian dapat disimpulkan, perencanaan strategis sistem informasi bertujuan untuk menghasilkan sebuah kerangka kerja rencana strategis SI/TI yang dapat digunakan pada UMN Al-Washliyah. Faktor-faktor penting tersebut dapat dilihat dari hasil analisis SWOT, Value Chain, PEST dan analisis lingkungan SI/TI. Pengambilan keputusan kategori promosi produk dilakukan dengan melihat tiga aspek yaitu Kembangkan, lanjutkan dan baru. Hasil dari analisa pendukung keputusan akan mampu membantu UMN Al-Washliyah dalam menentukan hasil rekomendasi SI di mana aplikasi Sistem informasi Tracer Studi menjadi target utama dalam pengembangan SI dengan nilai akhir 4,82 .

\section{REFERENCES}

[1] A. Wedhasmara, "Langkah-Langkah Perencanaan Strategis," J. Sist. Inf., vol. 1, no. 1, pp. 14-22, 2009.

[2] S. Kasus, C. V Grafika, P. Mitra, M. F. Johannis, A. R. Tanaamah, and P. Chernovita, "Metode Ward and Peppard," pp. 611-618.

[3] A. Bastian, "Analisis Strategi Bisnis dan Perancangan Strategis Sistem Informasi pada Perguruan Tinggi Swasta (Studi 
ISSN 2614-5278 (media cetak), ISSN 2548-8368 (media online)

Available Online at https://ejurnal.stmik-budidarma.ac.id/index.php/mib DOI 10.30865/mib.v5i2.2977

Kasus : Universitas Majalengka)," Infotech J., vol. 1, no. 1, p. 236699, 2015.

[4] S. S. Hilabi, "PERENCANAAN STRATEGIS SISTEM INFORMASI PERUSAHAAN DENGAN PENDEKATAN MODEL WARD AND PEPPARD (Studi Kasus PG.FANADA SUPER PLERED PURWAKARTA)," Techno Xplore J. Ilmu Komput. dan Teknol. Inf., vol. 1, no. 1, 2016.

[5] N. Sujana, "Perencanaan Strategis Sistem Informasi Dengan Pendekatan Ward and Peppard," Tematik, vol. 4, no. 1, pp. 68-85, 2017.

[6] Adriyendi, "Multi-Attribute Decision Making Using Simple Additive Weighting and Weighted Product in Food Choice," Int. J. Inf. Eng. Electron. Bus., vol. 7, no. 6, pp. 8-14, 2015.

[7] Y. Malau, "Sistem Pendukung Keputusan Pemilihan Kategori Promosi Produk Menggunakan Metode Profile Matching (Studi Kasus : Minimarket)," MATRIK J. Manajemen, Tek. Inform. dan Rekayasa Komput., vol. 19, no. 2, pp. 339346, 2020

[8] "Strategic Planning for Information Systems, 3rd Edition | Wiley.".

[9] "Kusrini Aplikasi Sistem Pendukung Keputusan - Google Scholar.".

[10] B. Sudrajat, "Pemilihan Pegawai Berprestasi Dengan Menggunakan Metode Profile Matching," J. Inf. Syst. Applied, Manag. Account. Res., vol. 2, no. 4, pp. 20-28, 2018.

[11] A. A. Tri Susilo, "Penerapan Metode Profile Matching Pada Sistem Pendukung Keputusan Pemilihan Ketua Program Studi (STUDI Kasus : Program Studi Teknik Informatika STMIK Musi Rawas),” JUITA J. Inform., vol. 5, no. 2, p. 87, 2018.

[12] P. Biyanti, "Perencanaan Strategis Sistem Informasi pada Universitas Islam Negeri Sunan Ampel Surabaya Menggunakan Metode Ward and Peppard," Tesis, 2018.

[13] A. D. Wahyudi, "Sistem Pendukung Keputusan Seleksi Penerimaan Staff Administrasi Menggunakan Metode Profile Matching," J. Teknoinfo, vol. 10, no. 2, p. 44, 2016.

[14] A. Mahari, "Universitas Muslim Nusantara Al Washliyah," Kultura, vol. 16, no. 11. pp. 5474-5478, 2015.

[15] U. S. P. Nasional, "Introduction and Aim of the Study," Acta Padiatrica, vol. 71, pp. 6-6, 1982.

[16] K. Subba Rao, "Standards of higher education," Curr. Sci., vol. 97, no. 9, p. 1276, 2009.

[17] V. Apriana, "Penerapan Profile Matching Untuk Menentukan Pemberian Beasiswa Pada Siswa Sekolah Menengah Atas," J. Mantik Penusa, vol. 3, no. 1, pp. 15-21, 2019. 